\title{
A man's role as a head, a burden or a blessing? An exploration of the African and Christian perspectives on the conventional role of a male person
}

\author{
Rev. Jacob Mokhutso - PhD Candidate \\ Biblical and Religious Studies \\ Faculty: Theology and Religion \\ University of the Free State \\ P.O Box 339, Bloemfontein 9300, Republic of South Africa \\ ORCID ID:0000-0002-1757-6829 \\ E-mail: MokhutsoJ@ufs.ac.za \\ Doi: https://doi.org/10.46222/pharosjot.102034
}

\begin{abstract}
In 2020, during a strict lockdown in South Africa, due to the COVID-19 pandemic, the country experienced an increase in gender-based violence (hereafter, GBV) cases perpetrated by men. Similar incidents occurred in August 2021, declared a women's month in South Africa, as a tribute to the over 20,000 women who marched to the Union Buildings on 9 August 1956 to protest against the extension of pass laws. Many scholars have tried to make sense of this, giving rise to diverse views about the causes of this phenomenon. Other scholars argue that men behave in this manner because of the high unemployment rate, as many businesses are struggling, due to a loss of revenue, as a result of COVID-19, and the government's lockdown measures. Other perspectives from different quarters indicate that GBV is due to stress and many other mental conditions, as a South African dwindling economy has impacted on families and caused losses of jobs and businesses closing. This is not the first time that the country has experienced these high cases of GBV. Over the years, men have and continue to commit heinous crimes and abuse each other, as well as women and children. This raises a question: Is this violence not a reaction by men to their role as heads of families and their socialisation by the African culture and Christian religion that teaches men to be heads of their households? Secondary data methods were applied in this research. The research found that men are under enormous pressure to meet society's expectations of them. That pressure has turned them into monsters who are not coping and instead kill themselves, their loved ones, or resort to violence.
\end{abstract}

Keywords: Man, curse, blessing, African, Christian.

\section{Introduction}

\section{Context, background, and importance of the topic}

The South African government has acknowledged, as indeed have most nations, that violence against women and femicide rates are a scourge. Violence against women affects everyone, irrespective of age, race, economic status, location, gender, and sexual orientation. South Africa remains committed, including at the highest levels of government, to address violence against women (Republic of South Africa, 2020). Modise (2021) noted that President Cyril Ramaphosa declared GBV a second 'pandemic'. Modise (2020) further noted that fears that cases of abuse 
would escalate during the COVID-19 lockdown became a reality - with the government making funds available to set up and equip shelters for affected women and children. President Cyril Ramaphosa also acknowledged this scourge, stating that, over the past three years, he himself has led the fight against this pervasive atrocity, including intimate partner violence, femicide as well as sexual rape and offences against women and girls (Republic of South Africa, 2020). Men commit a range of atrocities mentioned and acknowledged by the South African government. In 2018, Statistics South Africa released a report on how rife this scourge was in the country, stating that almost 50 per cent of the assaults were committed by a friend, an acquaintance (22 per cent), a spouse or intimate partner (15 per cent), a relative or other household member (13 per cent). Unknown persons committed approximately 29 per cent of the assaults. The report further mentions that one in five ( 21 per cent) partnered women has experienced physical violence by a partner (Stats SA, 2018). It also reports that divorced or separated women are more likely to have experienced physical violence or sexual violence (Stats SA, 2018). Bruce (2021) elaborates on how patterns of violence affecting women and men are quite different. Men constitute a large proportion of victims of homicide and other types of violence, where weapons are used to inflict serious injury. According to official figures, men, including male children, account for 85 per cent of victims of murder, over 80 per cent of victims of attempted murder, and over 70 per cent of victims of assault with grievous bodily harm. Women and teenage girls are the overwhelming majority of victims of sexual violence. Figures on rape released by the South African Police Service last week indicate that 90 per cent of victims over the age of 10 years are female. Girls and women, aged between 10 and 19 years, account for 21 per cent of these victims (Bruce 2021). Bruce (2021) further notes that men are overwhelmingly the perpetrators of violence.

Barker and Ricardo (2005:10) note that in some settings, young men's participation in conflict and use of violence become ways of obtaining empowerment, or are essentially viewed as a means to achieve and wield power, as they perceive no other way to achieve this. Young men may also find camaraderie with male peers in some armed insurgency groups, and, in some cases, male role models or surrogate fathers, and substitute families. This violence is about men being violent not only to women but also to each other, and is their way of finding recognition in society. Bruce (2021) also notes that violence is sometimes identified as a product of 'toxic' masculinity.

Toxic masculinity, in part, is the result of men becoming habituated to violence through violence from other men. The overall point is that men are violent, not only to women and children, but also to each other. Bruce (2021) elaborates on some aspects that lead to such violence. Many violent situations, where both parties are male, are disputes that escalate in intensity. The distinction between 'victim' and 'perpetrator' may be blurred. The person who is defined as the perpetrator may ultimately be the one who gets the upper hand in the confrontation. Men also tend to be more afraid of violence from other men than from women.

Robbers may anticipate that they are more likely to face violent resistance if the victim is male and armed. If the victim is male, this increases the likelihood that the robbers will resort to physical violence at any sign of resistance (Bruce, 2021). This raises a question: What makes men so violent? What is the contributing factor to this? Jacobsen $(2002: 11)$ adds that male-on-male violence takes an enormous toll among young men. Jacobsen (2002:11) further states that violence appears to be universally associated with men. Thobejane and Luthada (2019:11) mention that a man is not allowed to show his agony in public if he is in pain. This belief is exacerbated by the patriarchal nature of our society that suggests that men are not supposed to cry. These male victims are "hard-to-reach", because they prefer to be 'in a closet'. They may have a stigma for having shown that they are victims of female domestic abuse. 
Are these perhaps the triggers of the violence in question? Jacobsen (2002:2) further notes that men are troubled by other factors such as increased male unemployment, in particular, long-term unemployment, and there are concerns regarding the high rates of male violence in societies. Violence is proportionately perpetrated by men, and disproportionately men (except for domestic violence) are the victims. Jacobsen (2002:4) further adds that one possibility is that men's issues, to the extent that their impact is felt disproportionately among men of lower status (whether measured by income, caste, race, ethnicity, or social class) maintain higher invisibility in societies where persons of lower status are relatively more disenfranchised (even as they are more numerous). Indeed, it may be that males of lower status are worse off than women of lower status, in terms of relative enfranchisement within social and political support structures.

Thobejane and Luthada (2019:12) note that the Beijing Declaration for Action, established in 1995 and referred to as the Fourth World Conference on Women, identified 12 areas of concern that require urgent attention, in order to achieve the goal of gender equality. Violence against women is the most critical area of focus, and hardly anything has been done to address forms of abuse by men. This raises the question: Are men so violent because of the immense pressure society has exerted on them as heads of their families, despite the challenges of finances, health, and other factors? Men's decisions and behaviours are also profoundly shaped by rigid social and cultural expectations related to masculinity (MenEngage, 2014: 7). This research seeks to investigate this phenomenon by exploring both African and Christian perspectives.

\section{Problem statement}

Empirical evidence shows that men, in general, face immense pressure from religion and society, and more so because Africa is very religious. The teaching and socialisation by African traditional religion and Christian religion that a man is the head of the household prove very problematic. Is the violence perpetrated against women, children, and people with disabilities not a sign that men struggle to cope with their socialisation as heads of families? This research does not intend to justify the violence men commit against women, children, and people with disabilities. Rather, it intends to examine another angle of this topic of male violence and GBV, whilst all sectors of society are trying to remedy this. This study attempts to investigate the cause of, and recommend different approaches to remedy this violence, which has been declared a 'second pandemic' along with COVID-19 in South Africa.

\section{Changing landscape in gender equality in post-democracy South Africa}

South Africa is rated as one of the countries with the highest level of domestic violence against women and children (Thobejane \& Luthada, 2019:12). The government of South Africa has addressed a commendable issue, namely to deliberately level the playing field concerning gender. However, this has also caused challenges such as, among others, that women were prioritised to redress gender inequality. Meeting basic female needs such as education, health, land ownership and being role players in the economic sector was the starting point, while the foundations for strategic interventions to access productive resources and assets were also laid. The discourse on women's empowerment and gender equality in South Africa differentiated between 'basic or practical needs' and 'strategic needs'. The journey focused and continues to focus on women's empowerment by realising civil, political, and economic social rights (Background Paper: Women's Empowerment and Gender Equality 1994-2024). Access to essential services such as education, health, housing, welfare, energy and water, including women's control over these resources, especially in rural areas, were identified as the preconditions for meeting strategic 
needs. This was justified within the context of high levels of inequity and inequality impacting on women, as inherited by the new democratic government. The drivers of change were thus policy reform and building the institutional machinery. Policy and legal reform in priority areas have had a positive impact on women's access to basic needs (Background Paper: Women's Empowerment and Gender Equality 1994-2024).

Ngubane (2010:1) states that the abuse against women and children still prevails and feeds into the culture and tradition of male dominance. In some quarters, women are still denied their human rights, regarded as inferior to men, and more likely to be mistreated at the workplace, in the community, and in their relationships. Often, women are viewed as the property of men, first of their fathers and then of their husbands. Casimir et al. (2014:166) assert that the oppression of women is centuries old; in fact, it is as old as biblical history. Reasons adduced for this oppression range from the untenable philosophical arguments, superstitious cultural myths, humanities, and manufactured traditions that lack empirical evidence and smack of uncritical thinking.

Social trends over the past 20 years show that there have been dramatic changes within South African society regarding gender equality. According to the 2011 Census, a substantial number of households (41.2 per cent) were headed by females, with the percentage increasing with age. Complex household forms continue to dominate; marriage rates have declined, especially in customary marriages, and there has not been a shift towards a more nuclear family structure. According to StatsSA (2018:4) provinces where a high number of customary marriages were registered was in Kwazulu Natal and Limpopo which are amongst the most rural provinces in South Africa. A decline in customary marriages may be due to people residing in more urban provinces embracing westernisation, thereby preferring civil marriages than customary marriages. With evidence of a substantial increase in the economically active population, migration patterns are characterised by an increased urban influx of women aged between 20 and 34 years (Background Paper: Women's Empowerment and Gender Equality 1994-2024:12). The report further states that the journey of women's empowerment and gender equality in South Africa since 1994 has been promising but challenging. However, it is evident that, pre-1994, women had little choice about the kind of lives they wanted to live. Tremendous strides have been made in realising the rights of women post-1994 (Background Paper: Women's Empowerment and Gender Equality 1994-2024:7).

South Africa has also achieved significant strides in educational opportunities offered to females since 1994 (Background Paper: Women's Empowerment and Gender Equality 1994-2024:7). This fact is further elaborated on, giving a broader perspective of this achievement by the government. Nationally, the enrolment rate was estimated at 67 per cent in 2005, including an 11 per cent increase at the primary school level since 1997. By 2009, the Gross Enrolment Rate (Hereafter GER) at primary school level was 96 per cent for females and 99 per cent for males, indicating a GPI of 0.98 (Republic of South Africa 2009). At the secondary school level, the GER for females was 83 per cent, while it was 82 per cent for males, giving a GPI of 1.01. The 2011 Report on School Realities found that the lowest percentage of female learners in ordinary schools nationally was Grade 1 and Grade 4 (47.9 per cent in each case). The highest percentage was in Grade 12 (53.8 per cent) (Republic of South Africa 2011) (Background Paper: Women's Empowerment and Gender Equality 1994-2024:7).

Pre-1994, male enrolment dominated in institutions of higher education. However, post-1994, various reports demonstrate a positive trend towards gender parity across different institutions. At the post-school level, the percentage of adult men and women, aged 20 years and older, 
without any education, dropped between 1996 and 2011. Census 2011 reports that 8.6 per cent of the total population had no education. Of these, 7.2 per cent were male, and 9.9 per cent were female. While slightly more women than men have no education, this suggests that a large proportion of this population has had some form of education (Background Paper: Women's Empowerment and Gender Equality 1994-2024:7).

Since the Fourth World Conference on Women in Beijing (1995), tremendous advances have been made in terms of the rights and well-being of women and girls. We are still far from achieving equality between women and men, but we are closer to it, in terms of health, education, political participation, and income, than 20 years ago (MenEngage, 2014:8). Over the years, South Africa has started embracing and elevating women who were being treated as second-class citizens, due to patriarchy. This has emancipated women, who have been given a space to prove their gifts and abilities in areas historically occupied by men. In terms of health, there has been a tremendous improvement in how women are treated in health centres, where they now have a choice in how their bodies are supposed to be treated. Different birth-control methods are available and given free of charge to women in the country. There is also a drive to give free sanitary towels to underprivileged young women in schools. This is a sign that women's rights have become part and parcel of South African society. This also applies to a choice either to keep or to abort a foetus for all women from the age of 12 years (Background Paper: Women's Empowerment and Gender Equality 1994-2024).

Regarding economic opportunities, the number of females employed in the public sector has increased since 2008, although senior management positions are below the target of 50 per cent set by the government. The private sector has not been successful in improving gender equity. The number of female directors and executive managers in private companies has decreased from 58 in 2008 to 41 in 2010 among the top companies that claim to be 'engendered'. In the companies listed on the Johannesburg Stock Exchange (JSE), only 4.5 per cent of chief executive officers (CEOs) and 19.3 per cent of executive managers are women, with 73 companies not having a woman on their boards of 24 directors (Republic of South Africa 2013; Background Paper: Women's Empowerment and Gender Equality 1994-2024:23.24). Ngubane (2010:1) adds that women in South Africa have gained substantial rights and opportunities since 1994. Women, especially Black women, have been on the bottom rung of the ladder regarding participation in the country's economic, social, and political life. For many years, Black women have experienced discrimination against them based on class, race, and gender (Ngubane, 2010:16).

\section{The African and international review of the changing global landscape in gender roles, and its impact on modern man}

Barker and Ricardo (2005:10) note that urbanisation, the expansion of formal education, and the increased enrolment of girls in public education have led to changes in gender roles. Various studies and research for this report confirm that many young men simultaneously hold traditional and rigid views about gender alongside newer ideas about women's equality. Jacobsen (2002:2) shares an increased interest in male challenges such as economic concerns regarding increased male unemployment, particularly long-term unemployment; concerns regarding the reduced proportion of men in higher education; concerns regarding how boys fare in primary and secondary education, and social concerns regarding the high rates of male violence in societies, for violence is highly disproportionately perpetrated by men and disproportionately claims men (except for domestic violence) as victims. Jacobsen (2002:2) adds that other issues include fatherhood and reproductive health. Jacobsen (2002:6) shares the changes that have come into 
play with the improvement of women, namely changes in roles and identities in families, the workforce, and society that men are currently facing, both in developing countries that transit from a pre-industrial to an industrial economic organisation and developed countries that are currently undergoing a transition to post-industrial states.

There is an increasing amount of evidence from the medical and scientific communities that men are disadvantaged in comparison with women, in terms of relative robustness (Jacobsen, 2002:7). Barker and Ricardo (2005:2) mention not only young men who have been combatants, but also young men who are survivors and victims of violence, young men displaced by conflict; young men orphaned due to conflict; young men who are brothers or husbands of women who have been sexually abused during the conflict, and young men who have been forced to carry out sexual violence, among others. This changing landscape has altered or challenged the socialisation of many men who cannot cope with their new roles, as women have become more educated, are employed, and are breadwinners in their households.

In many parts of the world, unemployment and underemployment of men, economic stress due to the global recession, and income instability are associated with adverse mental health. Results from the International Men and Gender Equality Survey mentioned earlier indicate that a relatively high proportion of men report that they are frequently ashamed to face their family or are stressed or depressed as a result of having too little income or being unemployed or underemployed. In India, for example, out of 1,552 men interviewed in the household survey in two cities, 30 per cent (regardless of their current employment status) stated that they are ashamed to face their family, because they have been out of work or do not have enough income (United Nations, 2011:22). The World Population Review produced a report of suicides statistics by country, noting that South Africa is among the top ten countries with high suicide rates. This report notes that roughly 23.5 people committed suicide in South Africa, of whom 37.6 per cent are men and 9.8 per cent are women (World Population Review, 2021).

Jacobsen (2002:17) mentions the reduced participation of men, at least relative to women, in "formal" economic work, the corresponding lack of increased male participation in the informal sector, including childcare (leading to a net increase in the work performed by women), and strains on social and family structures caused by the apparent obsolescence of traditional male roles, with insufficient new male role definition to offset this trend positively. If the world changes, then gender roles for both genders also need to change.

Jacobsen (2002:17) adds that the reconfigurations in the occupational and industrial structure of the vast majority of developed countries that began in the 1970s reached full force in the 1980s and 1990s, with reverberations into the organisation of work in the industrial sector in developing countries. Unionised sectors, which were heavily male, lost ground in employment and wage setting. In the United States, after a relatively stable period, the female/male wage ratio began to rise steadily in the 1980s, mainly because male wages were falling. This trend was not observed in other developed countries, due partly to greater wage-setting and different timing of antidiscrimination laws. In the late 1970s, women in developed countries moved into the labour force and into the growing sectors of the economy in increased numbers (Jacobsen, 1991).

Nonetheless, a growing number of accounts of young men's participation in conflict settings have made an association between masculinities, or the socialisation of boys into rigid gender norms, and violence as well as conflict. Various accounts and research for this study affirmed that the lack of employment that provides income and social recognition is linked to young men's participation in armed conflicts. Jacobsen (2002:19) mentions reverse discrimination, where a 
question is asked as to what degree the increase in women's formal labour supply has led to the 'crowding out' of men. To the extent that these are the relatively disadvantaged male members of the labour force, the increase in women's participation disproportionately affected the worse-off men. In the August 2015 Report of the Department of Women, the then Minister Susan Shabangu states that the report illustrates excellent strides made by women across the different levels of education. However, as noted in this report, educational advancement at the higher level (Masters and Doctoral degrees) wanes. This is apart from the fact that women dominate the services sector less than the sciences sector. Bryner (2007) states two main reasons which are the reasons why men dominate sciences sector than women such as socialization, where young girls are taught from an early age that certain jobs are meant for men not women. Secondly, family responsibilities which are mainly a responsibility of women to rather choose family than a career that may interfere with this responsibility. As a society, South Africa has achieved considerable progress in many aspects of women's economic empowerment through, among others, increases in educational attainment, labour market participation, access to credit, land and properties, reduced poverty and inequality, and share of paid work (Republic of South Africa, 2015:6).

\section{The context of an African man}

Barker and Ricardo (2005:5) add that society informs a man about what is expected from him through formal and informal means such as jokes, social ridicule, and insinuations. A nonconformist is made aware of his difference. Society exerts intense pressure on anyone who deviates from the socially accepted gender roles, letting a male know when he is failing to be a man' (Social Sciences and Reproductive Health Research Network, 2001:97).

Cornwall (2003) notes that men's social recognition and sense of manhood suffer when they are unemployed. For example, in the Yoruba regions of Nigeria, there are documented accounts of women belittling husbands when they cannot provide financially for the family; men themselves report feeling emasculated when they cannot contribute to family income. In such settings, relationships between couples may become tenuous or stressed; some young married women keep their possessions in their father's house as a precaution in the case of having an "economically unviable" husband (Cornwall, 2003). In South Africa, for example, conflicts have occurred between rural-based elder men and wage-earning younger men who migrate to cities for work. Many migrant workers from countries such as Mozambique, Lesotho, Swaziland, Botswana, Zimbabwe etc. send income to their families, thus maintaining their status as men, even if they are not physically present. Migration to cities and modernisation have become ways for young men to usurp the power of elders. In some settings, migration to cities for work has become part of a new rite of passage (Barker \& Ricardo, 2005:12).

The underlying syllogism is as follows: If adult manhood equals work, not having work means not being socially recognised as an adult man. For many men, not having work results in shame, stress, depression, and lack of social identity. In some settings, some young men are increasingly likely to engage in delinquency, armed violence, or other antisocial behaviours. Men's employment status also plays a role in determining when they can form families, whether they can contribute financially to their families and, in some cases, whether they live with their children. If men globally derive their identities and chief social function from their role as providers, what happens when men are without work or do not have sufficient income to meet the social expectations as providers? (United Nations, 2011:21). For the vast majority of young men worldwide, stable employment is the pathway to being socially recognised as adult men, associated with the family formation in most parts of the world (United Nations 2011:23). In South Africa, a Zulu says Ubuhle bendoda zinkomo zayo (A man's manliness is reflected by the number of cows he has.). Khumalo (2019:3) explains that this song is sung mainly by the bridal party at 
traditional Zulu and Xhosa weddings. According to Khumalo (2019:3), this song reminds the bride that she must not forget that the man's attractiveness or handsomeness is measured by the cattle that he offered as her lobola.

In African culture and traditional African life, gender is defined according to roles and functions in society. Dickie (2019:2) elaborates that Individuals holding traditional gender role beliefs support women's role as the caretaker at home and in the family and men's role is to provide financial support as the breadwinner of the family. Research has shown that traditional gender role beliefs are more strongly endorsed by men than women. What it means to be male or female in a particular society shapes the opportunities one is offered in life, the roles one may play, and the kinds of relationships one may have (Ngubane 2010:2). Religion and culture have profoundly influenced women's role in South African society and powerfully shaped social identity (Background Paper: Women's Empowerment and Gender Equality 1994-2024:6). Other factors that affect young men in Africa, as mentioned by Barker and Ricardo (2005:15), are the challenges of young men who were combatants, including young men as survivors and victims of violence; young men displaced by conflict; young men orphaned due to conflict; young men as brothers or husbands of women who have been sexually abused during the conflict, and young men who have been forced to carry out sexual violence, among others. The other point to note is that, in every GBV incident, there is a young man in the background or foreground who sees his mother, sister, aunt, relative or neighbour being abused. Nothing much is said about the scars these young men carry and how their experiences impact on them when they become adults. As Ruddick states: "In all wars, on any side, there are men frightened and running, fighting reluctantly and eager to get home, or even courageously resisting their orders to kill."

Furthermore, Barker and Ricardo (2005:15) note another challenge that many young men face in Africa: they are often stigmatised and regarded as criminals, delinquents or potential or actual troublemakers or predators. The George Floyd case from the USA that took place on 25 May 2020 is an example of this. In the African context, the language used to refer to young men, meagre income, and urban-based young men is often pejorative. This is nearly the case with young Black men in South African townships, where there is a lack of opportunities, and many have given their lives to cheap drugs such as dagga (marijuana) and Nyaope. Monyakane (2018:206) explains Nyaope as a:

\begin{abstract}
Concoction of dependence producing substances such as dagga and heroin as well as some of domestic toxic chemicals. Nyaope (It is a Tswana word meaning Mishmash-a useless thing. Once addicted you turn into a useless thing) drug bears other names depending on the location of exchange. The name Nyaope originated in Gauteng Province, Tshwane South Africa. In KwaZulu Natal South Africa, Nyaope is called Woonga. (This name is due to the sound it makes as it penetrates the abuser's mental parts.) It has differing trends of mixtures.
\end{abstract}

One can imagine the impact of carrying such a stigma throughout one's life simply because of one's economic status and the environment in which one lives and from which one comes. For example, Barker and Ricardo (2005:16) further note that they are the young men bussed in and paid to participate in clashes between Muslims and Christians in Nigeria or recruited by the Revolutionary United Front (RUF) in Sierra Leone. But it is essential to affirm that the vast majority of young men with low income in sub-Saharan Africa are not involved in conflicts or armed violence. They are often presumed guilty simply by being young, unemployed, out-ofschool, poor and male. 
Barker and Ricardo (2005:15) note the different challenges that men generally face in Africa in terms of the following realities of men:

- Rural-based young men in Botswana, historically responsible for herding cattle, are more likely to drop out of school than their sisters.

- Out-of-school young men in northern Nigeria cannot marry, because they are out of work, and sometimes participate in ethnic violence.

- Young men in townships in newly democratic South Africa.

- Young men abducted by the Lord's Resistance Army (LRA) to serve as combatants in northern. Uganda, or living in camps for internally displaced persons.

Barker and Ricardo (2005:15) also mention that, while women have gained substantial rights such as a right to education, health, employment, credit, property ownership etc. and many other opportunities in recent decades, still gender inequality still prevails. African culture promotes patriarchy in many ways, thus perpetuating women's subordination (Ngubane, 2010:22). In African culture, decision-making has traditionally been a male prerogative. Family planning decisions were also solely made by a man. Women may be subjected to continuous childbirth by their husbands or in-laws against their will (Ngubane, 2010:26). Furthermore, multiple discourses on masculinity confuse men (Van Klinken, 2011:123).

Barker and Ricardo (2005:2) state that, in Africa, the association of masculinity with violence and risky behaviour has important implications for the efforts of development agencies and governments to reduce violence, vulnerability to civil conflict, and the spread of the HIV/AIDS pandemic. However, this assertion does not fully define whether this is a cultural reaction or a generally experienced phenomenon in Africa. However, Barker and Ricardo (2005:9) qualify this, stating that there are no versions of manhood in Africa that are socially constructed; fluid over time and in different settings, and plural. There is no typical young man in sub-Saharan Africa and no single African version of manhood. There are numerous African masculinities, urban and rural, and changing historically, including versions of manhood associated with war, warriors, and others associated with farming or cattle-herding. There are indigenous definitions and versions of manhood, defined by tribal and ethnic group practices, and newer versions of manhood shaped by Islam, Christianity and Western influences, including the global media. Barker and Ricardo (2005:9) further highlight that men's socialisation in Africa requires of them to achieve a certain level of financial independence either through employment or any form of income. Achieving that goal means that one can afford to pay lobola (bride price), marry, and have a family of their own (Barker \& Ricardo, 2005:9). In their research, Barker and Ricardo (2005:9) concluded that men's social recognition and sense of manhood suffer greatly when they lack income or are not employed. Young men who do not achieve this societal expectation often resort to violence or gang-related violence.

\section{The role of a man in African traditional culture}

It is interesting to note that the issue of the headship is not only a concept affecting Africans, but the biblical perspective that addresses the issue, among others. For some African Christians, Ephesians 5:22-24 is a basis for the entrenchment of the traditional view of the husband-wife relationship (Ademiluka, 2021:1). In Ephesians 5:22-33, Paul commands wives to be subjected to their husbands, while husbands should love their wives as Christ loved his Church; the wife must submit to her husband, because the husband is the head of the wife (v. 23). Taken literally, 
this injunction resonates with the African patriarchal view of marital relationship, in which authority is generally "wielded by the husband while the wife is simply expected to submit to his authority" (Adams, 2003:1). As Casimir et al. (2014:170) put it: In African societies, the traditional gender roles are usually maintained by a system of patriarchy which sees men as pre-eminent human beings and women as secondary human beings whose roles are meant to complement those of men. Discrimination against the women begins with the girl child to whom the male counterpart is often preferred. The major reason for this is that girls are "perceived as expendable commodities which will eventually be married out to other families to procreate and ensure the survival of the spouses' lineage by bearing sons" (Igbelina-Igbokwe, 2013:2). If a woman gives birth to girls, other men will marry a second wife or even divorce their first wife.

Barker and Ricardo (2005:5) share that the chief mandate or social requirement for achieving manhood in Africa - for being a man - is to achieve some level of financial independence, employment, or income, and subsequently start a family. In the greater part of Africa, where bride price is commonplace, marriage and family formation are thus directly tied to having income and property. A young man interviewed in Lira, northern Uganda, put it simply: "To call oneself a man it is simplest after (one is) married with children. No children and you are still a boy." Barker and Ricardo (2005:5) share that manhood has to do with maturity; however, when unmarried, a man is viewed with suspicion and often precluded from certain social positions. He is also viewed as irresponsible and perhaps even as homosexual. In the Eastern zone, the consequences of not marrying are dire for a man. He is forbidden from holding specific titles, and in the event of his death, he cannot be buried like a married man (Social Sciences and Reproductive Health Research Network 2001:102).

Many cultural groups in Africa have developed and continue to carry out initiation practices or rites of passage, some of which include male circumcision, as part of the socialisation of boys and men. Such practices are widespread in West Africa and much of East and Southern Africa, with tremendous local and regional variations. These initiation rites (with frequently analogous processes for young women) often include the seclusion of young men from their families (and from women and girls) and some informal learning process, during which older men pass on the information and skills that are considered necessary to be an adult male in their societies. These skills may include hunting, treating women, building a house, warrior or fighting skills, and historical information about the cultural group and its rituals (Barker \& Ricardo 2005:9).

Among ethnic groups in Africa that rely on cattle herding for subsistence, manhood begins when the father bestows land and cattle or other livestock to the son, which can either serve as a bride price (Iobola) or enable him to achieve the status of manhood and form a family. In this way, achieving manhood depends on an older man (one who holds more power) who decides when a young man can achieve socially recognised manhood. This issue of older men holding power over younger men will recur throughout this analysis. Similarly, in Botswana, men often support two or more households, depending on their age and role in the extended family. They may support a residential family consisting of a wife, children and some of the wife's family members and may also be responsible for supporting their parents. In this setting, men rarely establish their households before the age of 40 years. Indeed, younger, unmarried men contribute to their parents' households by forming their own families (Barker \& Ricardo, 2005:6).

\section{The impact of men's socialisation on their health}

The African understanding of a man has been very problematic, because it gives men the impression that they are super-human and that they are pressured by society to attain perfection. 
Staiger et al. (2020:1) share some of the effects of this notion, stating that this also affects men's health. When scrutinising other studies, they indicate that men are more reluctant to seek help for mental health problems than women. Traditional ideas of masculinity are often regarded as a cause of this phenomenon. In South Africa, President Cyril Ramaphosa indicated that a slow rollout of vaccines occurs among men who fear that the vaccination may affect their sexual performance. This implies the pressure men face in risking their health, in order to meet society's expectations.

Staiger et al. (2020:2) further note that the socialisation of the vast majority of men informs them that mental illnesses such as depression are a sign of powerlessness and lack of control, which are not associated with an African man. Staiger et al. (2020:4) interviewed men who struggle with depression. They raised the fact that men's socialisation, in general, emphasises avoiding feelings of helplessness, appearing strong, and never crying. One participant reflected on the fact that masculine norms mean that he must never disclose mental health problems, saying that "it doesn't exist among men. Men are the breadwinners, the problem solvers, but the doers". Staiger et al. (2020:7) further note that hegemonic masculinity is defined as the dominant cultural ideal in Western countries, which serves as a normative orientation for men concerning heterosexuality, rationality, success, strength, or control. However, only a few men might conform to these ideals. Ridge et al. (2011:1149) argue that men feel subjected to external pressures (for example, work), with the body being instrumental in interfacing with the world and achieving masculine status. However, men are also encouraged to construct a largely autonomous self that is 'in control' (even to the point of avoiding help during a known medical emergency). Men thus experience conflict between having choices and being constrained by their social circumstances. Ridge et al. (2010:149) further note that, roughly 30 per cent more often in men, alcohol and substance use may mask distress among men. Ridge et al. (2010:150) mention that the dominant narrative about masculinity in the literature is that men are more reluctant to seek help than women, regardless of their health concerns.

Naved et al. (2011:9) also note that a large portion of urban (70 per cent) and rural (63 per cent) men reported experiencing some form of emotional abuse. It is noteworthy that almost one-third of urban men and one-fifth of rural men reported seeing or hearing their mother being beaten by her husband or boyfriend. However, the most common emotional abuse experienced by urban men (45 per cent) was being told that they are lazy, stupid, or ugly by someone in their family.

\section{Christian perspective on the role of men}

The religious teachings on gender in a society have an great role to play on the lives of especially young girls and women. Consequently, Christians have a responsibility to accurately understand biblical teachings on gender in what is now becoming a fairer society on gender issues. Attah (2017:159) states that religion is part of the culture in its broader sense and creation of society. Burkert (1985:16) comments that there has never been a society without religion. African women theologians are very critical of Christian churches. In the words of Oduyoye, they continue to use the Hebrew Scriptures and the Epistles of St. Paul to reinforce the norms of traditional religion and culture (Van Klinken, 2011:110,111). Interestingly, the concept of 'headship' is not a foreign concept from the Bible. It was used in Pauline letters such as Colossians 3:18 and Ephesians 5:21-24. In essence many Christians today consider gender based on the idea of "neither male nor female" (Galatians 3:28), but in reality much is still based on 1 Corinthians 11:3: "The head of every man is Christ, and the head of the woman is the man, and the head of Christ is God." This is considered to be the natural order where the man is the "head" kephale, of the woman which in Greeks also means "source" or "origin." (Lampadarios, 2006; Nicolaides, n.d.). 
Hence, Attoh (2017:159) argues that religion supports the patriarchal society, private property, and class society. Religion has influenced the relationship between men and women for centuries and entrenched male domination in the social structure of society, thus helping to reinforce patriarchy. Many of the practices such as the notion of monogamy with its attendant female subordination and domestication, which are portrayed as part of culture or religion, impinge on human rights, are gender-specific, and preserve patriarchy at the expense of women's rights. Attoh (2017:159) further argues that such patriarchal practices include a preference for male children, thus leading to female infanticide through abortion by those desirous of having male children, especially in some parts of the country where the girl child cannot inherit from her family of orientation and women are viewed as chattels of their husbands.

Casimir et al. $(2014: 166,167)$ note that the ironical bend to this history derives from the fact that man has always respected and honoured "truths" from religion and theology as sacrosanct and unquestionable. The theological interpretation of man's relationship with the woman is regarded with the same unquestionable awe with which all church-derived biblical canons are treated. They are regarded as the law of God which mere mortals cannot question. But the church's interpretation of the Bible was carried out by a specific group of men inspired by God's word. Yet they are human mortals and subject to human errors of faith and reasoning (Casimir et al., 2014:167). By contrast, women in Africa looked up to the colonial church as the saviour that would liberate and restore their tradition-denied human rights and opportunities for human development. The church supported the ancient and modern bearers of the culture in drawing up and sustaining a paternalist gender structure and constructs that perpetuated inequality and injustices against women (Casimir et al., 2014:167).

One can effectively posit a hermeneutical problem of misinterpretation of biblical and African cosmological values that are responsible for the worst form of oppression and maltreatment against women for centuries in Africa. For millennia, people believed that women's traditionally assigned unequal status of inferiority and second-class citizenship about men was directed by God and biblically supported (Ani, 2013:21-24). Ademiluka (2021:8) argues that Ephesians 5:2233 is part of 5:22-6:9, which reflects the household codes written by the ancient Greek philosophers to uphold the power differential between husbands and wives, parents and children, as well as masters and slaves. The author wants to point out that, in the original Greek, there is no 'submit' in verse 22, but it was assumed later since it was read in verse 21 In other words, the best translation would have been to combine verses 21 and 22 , so that the translation could be: "Submit to one another out of reverence to Christ, wives to your husbands as to the Lord. For the husband is the head of the wife." (5:4). The verb's root is 'hupposatou', which means 'to obey or to submit'. Gabelian (1978:75) indicates that the verb occurs 23 times in Pauline letters and denotes subordination to those considered worthy of respect, either because of their inherent qualities or more often because of their position. To avoid unnecessary mistakes, wives must subject to their own (Greek "idios") husbands (Colossians 3:18). Gundry (1977:72) implies this when he states: "The rule as here laid down in general, binding on every member of the church, regardless of sex, men as well as women, husbands as well as wives. No room for preferential rights." The idea of male domination is erroneous. For example contrary to what many believe, the woman's role and function is no less than the man's but it is indeed varied. Men are called to lead worship according to Paul: "I desire then that in every place the men should pray, lifting holy hands without anger or quarrelling" (1 Timothy 2: 8). Women on the other hand are ordered to keep silent and are not permitted to have authority over men or to teach (1 Timothy 2: $9-12$ ). (Nicolaides, 2010). 
These codes reflect the conviction of the ancient Graeco-Roman society of the $1^{\text {st }}$ century that women were inferior to men and that the husband's role was to rule his wife. In Ephesians 5, Paul borrows this writing pattern, but mitigates the absolute authority of the male head of the house. Contrary to the absolute authority of husbands in the Graeco-Roman world, Paul likens the authority of the Christian husband over his wife to Christ's headship over the church. As Christ gave himself up for the church, the Christian husband should place more value on the life and well-being of his wife than on his own life and well-being. Jesus Christ in all his utterances and actions provides us with a perfect example concerning how we ought to treat women as equals, and not subordinate their roles (Matthew 12:49-50; 15:38; 25:31-46; Mark 3:34-35; Luke 8:21; 11:27-28). Jesus treatment of women as equals defied all the judicial, social, and religious customs of the time. Legalistically speaking, concerning female rights on all issues he treated the genders equally. Jesus accepted women's intelligence and spiritual capacity, and treated them with utter respect, as is clearin the spiritual truths he imparted to women such as the Samaritan woman (John 4:10-26) and Martha (John 11:25-26).

In a society that disapproved of the religious education for women, Jesus encouraged women to be his disciples and was emulated in such an endeavour by his followers, for example Paul:

\begin{abstract}
"Paul affirms men and women are equally "in God's image," "in Christ," given dominion over the earth, and given the creation mandate and blessing. Much of his theology logically entails their equality: servant leadership, "mutual submission" in church and marriage, the oneness of the body of Christ, the priesthood of all believers, the gifts of the Spirit for all, liberty in Christ, inaugurated eschatology, the new creation, and "there is no male/female division" in Christ Payne, 2009 cited in CBE International).
\end{abstract}

\title{
Patriarchy
}

Masculinity studies have coined the concept of masculinity as a plural, masculinities, as a means to overcome a dichotomous notion of gender as male dominance and female subordination (Van Klinken, 2011:123). R.W. Connell has developed a theory on masculinities, distinguishing between hegemonic masculinity (the dominant form of masculinity in a society prescribes the image of a real man) and other forms of masculinity that are subordinated to, complicit with, or marginalised by the hegemonic one (Van Klinken, 2011:123).

Susan Shabangu, Minister in the Presidency Responsible for Women, stated that cultures, social systems, and religions have, in the past, promoted patriarchy and the oppression of women. Discrimination against women has taken on various forms, from disenfranchisement to diverse forms of abuse. Patriarchy, the philosophy underpinning women's subordination, on the one hand, and male supremacy, on the other, are often referred to as the oldest forms of discrimination in the world. A truly international phenomenon continues to discriminate against women systematically and impedes the efforts of this democratic government in empowering women. In South Africa, discrimination against women was compounded by the apartheid system, resulting in the oppression of Black women in terms of race, gender, class, or other disadvantaging factors. Hence, there is a need to empower women (Republic of South Africa, 2013).

\section{Colonisation}

Colonisation undermined and upset some of the powers of the traditional big men or created new big men backed by colonial powers. From colonisation, African men and manhood have often 
been constructed about European manhood. For example, historically, the term 'boy' means maleness, social immaturity, and inferiority before adult men, mainly White men. European men used the word to insult African men and African elders to keep the younger generation of men "in their place" (Lindsay \& Miescher, 2003: 5). A review of the historical literature on African manhood reveals numerous examples of colonisers who questioned or criticised the masculinities of the colonised (Barker \& Ricardo, 2005:12). In other cases, African men are sometimes co-opted into subjugating African men, such as the Hutu and Tutsi in Rwanda and Burundi, as well as Black police officers and Black members of the armed forces in apartheid South Africa.

\title{
Discussion
}

This research attempted to show that the teachings and socialisation of men as heads of households is too great a burden to bear and outdated in our times. The emphasis that men should be in charge of all aspects of life perpetuates the violence experienced by women worldwide. Gender equality has proved the ill-informed notion that women are lesser human beings than men. Women have shown themselves to be competent in doing anything that men can do. This is noticeable in academia, business, politics, sports, and many other sectors. Women have owned their spaces and contributed immensely to the world.

This research attempted to argue that the notion that men are heads, despite changes in gender roles and lessons that society had to learn and relearn regarding this subject matter, is detrimental to society. Recently, for example, South Africa was shocked by the killing of a law student at the University of Fort Hare. Daymani (2021:1) reports that Aluta Pasile, the man accused of murdering her, mentioned that:

\begin{abstract}
Mtebeni had been asleep on the night of the 16th of August, but he managed to steal her cellphone and unlocked it after guessing the password. According to Ngcakani, Pasile, in his confession, said he saw "love messages between her and another boyfriend", as well as a photo of the other man. The following day, after confronting her about what he had found on her cellphone, they got into an argument, which became physical, Ngcakani said. "He alleges that she bit him and scratched him all over the body and, in retaliation, he pushed her against the wall, resulting in her sustaining fatal injuries." To cover up, Pasile bought tools to cut her up and dispose of the body, Ngcakani said. Mtebeni's dismembered body was found stuffed inside a suitcase and a bag on the corner of Fitzpatrick Road and Fleet Street on Thursday. Her head and hands were found in Pasile's possession in a room they shared in Quigney.
\end{abstract}

This story and many others which are reported daily show that the vast majority of men feel entitled to women with whom they are in a romantic relationship. They own them. Hence, Pasile felt that he should kill his girlfriend so that no one else could have her. A head is in charge. This research argues that this notion that a man is a head is toxic and at the forefront of the violence in South Africa, Africa, and the world. This research argues that, instead, society should emphasise that men are human beings first before they are heads of their households. The tables have turned; women worldwide have been empowered and given opportunities in all sectors of society; this is the world's reality. Therefore, it is detrimental to continue preaching the African cultural and Christian view that men are heads of their households. Instead, society should investigate another or a different narrative that will assist men to adapt to this new reality. Gone 
are the days when men were in charge, all genders were in charge. All genders, cultures, and religions should adapt to this new reality - to have a healthy society.

This emphasis will assist in removing the burden of earning more money, struggling with divorce, especially if a woman wants a divorce, dealing with issues of infertility, unemployment, and health challenges. Being a human being means that one has shortcomings, and that one's faculties have limitations. A human being gets ill, weak, and fails, in some instances.

The narrative preached by religion and culture over the centuries has damaged society and men. The reality is that, with the current world economy, not all men will find a job, have a degree, be a perfect father, or father a child. Other men may not even have the leadership skills that their partners may have to lead their families. Men being heads does not allow them to quickly accept and adjust to the failures they come across. According to imperial evidence, this leaves men shameful, and the shame leads to suicide, bottled up anger, abuse of alcohol and drugs, as well as being violent to their loved ones. It is high time that religion and culture review the impact of this narrative that continues to destroy men and society.

\section{Conclusion}

This research focused on the changing landscape in both Africa and the world. Increasingly more countries have given women many opportunities to uproot the heritage of patriarchy and colonisation. The world should embrace this gift, a new normal; the gift women bring in different sectors of society will be hard to comprehend, as males still feel that they should dominate with the wounded men of the world. Culture and religion have and continue with patriarchal narrative, and it is high time to challenge that narrative. This research attempted to bring an alternative narrative that may lessen the burden and shame with which the vast majority of men live, due to their inability to meet society's requirements of their roles as men. Men are human beings first before they are fathers, breadwinners, and every other role society has given them. This means that, like all other human beings, they can express emotions, weaknesses, ask for help, fail, and struggle. Being a man does not mean being a super-human. If this narrative is accepted, men will be partners, fathers and citizens who can be spiritually, physically, and psychologically healthy breadwinners.

\section{References}

Adams, D. (2003). 'The transformative ethos of Ephesians 5:21-33 and its implications for a contemporary South African context', MA thesis, University of Stellenbosch, Stellenbosch.

Ani, C. K. C. (2013). Redefining the Concept of Women Empowerment: The Vision and Quest for Equality and Partnership in the Post 2015 Development Era. Special Gender and Development Publication, New York: United Women (UNIFEM).

Ademiluka, S.O. (2021). For the husband is the wife's head: A contextual re-imagining of Ephesians 5:22-33 among Nigeria Yoruba Christians. In die Skriflig/In Luce Verbi, 55(1), a2613. [Available online at https://doi.org/10.4102/ids.v55i1.2613]

Attoh, F. (2017). Gender, religion and patriarchy: A sociological analysis of Catholicism and Pentecostalism in Nigeria. Advances in Social Sciences Research Journal, 4(14), 158-170. 
Barker, G. \& Ricardo, C. (2005). Young men and the construction of masculinity in sub-Saharan Africa: Implications for HIVIAIDS, conflict and violence. Social Development Papers. Conflict prevention and reconstruction. Washington DC: The World Bank.

Breines, I., Connell, R. \& Eide, I. (eds.). (2000). Male Roles, Masculinities and Violence: A Culture of Peace Perspective, Paris: UNESCO Publishing.

Bruce, D. (2019). "Ignore male victims at society's peril" Mail and Guardian, 19 December.

Burkert, W. (1985). Greek Religion, Cambridge, MA: Harvard University Press.

Bryner, J. (2007). "Why men dominate math and science fields" LiveScience, 09 October.

Casimir, A., Chukwuelobe, C.C. \& Ugwu, C. (2014). The church and gender equality in Africa: Questioning culture and the theological paradigm on women oppression. Open Journal of Philosophy, 4, 166-173. [Available online at http://dx.doi.org/10.4236/ojpp.2014.42024]

CBE International (2016). Biblical Gender Equality: A Summary by Payne, P.B. - December 2016 [Available online at https://www.cbeinternational.org/resource/article/biblical-gender-equalitysummary]

Cornwall, A. (2003). 'Whose Voices? Whose Choices? Reflections on Gender and Participatory Development', World Development, 31(8), 1325-1342.

Diekie, A.L., Safavian, N. and Eccles, J.S. (2019). Traditional Gender Role Beliefs and Career Attainment in STEM: A Gendered Story? Front. Psychol. 10:1053. doi: 10.3389/fpsyg.2019.01053

Gaebelein, F. E. (ed) (1978). The expositor's Bible commentary. Vol. 11. Grand Rapids, Michigan: Zondervan.

Hamermesh, D. S. (1986). "The Demand for Labor in the Long Run." In Handbook of Labor Economics 1, Orley Ashenfelter and Richard Layard (eds.), Amsterdam: North-Holland, pp. 429471.

Lindsay, L.A. \& Miescher, S.F. (Eds.) (2003). Men and Masculinities in Modern Africa, Portsmouth, NH: Heinemann.

Igbelina-Igbokwe, S.O. (2021). 'For the husband is the head of the wife': A contextual re-reading of Ephesians 5:22-33 among Nigerian Yoruba Christians. In die Skriflig, 55(1), a2613. [Available online at https://doi.org/10.4102/ids. v55i1.2613]

Jacobsen, J.P. (2002). What about us? Men's issues in development. Wesleyan Economics Working Papers 2002 - 001 . Wesleyan University, Department of Economics: Middletown.

Khumalo, A. (2019). Ubuhle bendoda zinkomo for choir and voice: Transcribed from the embodied knowledge of Dr Andile Khumalo by JIWE Publishers for the SAMRO Foundation's Indigenous African Music (AIM) Project. Braamfontein, Johannesburg. 
Lampadarios, P. (2006). Orthodox Teachings. Archbishop of Pelusium, Greek Orthodox Archdiocese of Port Said: Egypt.

Lindsay, L.A. \& Miescher, S.F. (Eds.) (2003). Men and Masculinities in Modern Africa, Portsmouth, NH: Heinemann.

Monyakane, M. M.E. M. A. (2018). Rehabilitative South African Criminal Law Response to Nyaope, Drug Addiction: - A Recommendation for Health Oriented Nyaope Drug Weaning. Res Pediatr Neonatol. 3(1). RPN.000554.2018. DOI: 10.31031/RPN.2018.03.000554

MenEngage Alliance; UN Women; \& UNFPA (2014). Men, masculinities, and changing power: a discussion paper on engaging men in gender equality from Beijing 1995-2015. New York, USA: UNFPA.

Modise, K. (2021). (2021). SA's second pandemic of 2020: Gender-based violence. Eyewitness News 18 June.

Naved, R.T., Huque, H., Farah, S. \& Shuvra, M.M.R. (2011). Men's attitude and practices regarding gender and violence against women in Bangladesh: Preliminary findings. Icddr,b: Dhaka.

Ngubane, S. J. (2010). Gender roles in the African culture: Implications for the spread of HIV/AIDS. Unpublished Masters dissertation, University of Stellenbosch, Stellenbosch, Cape Town.

Nicolaides, A. (n.d.) A reflection on the past and present role of women in the Greek Orthodox Church, in press, to be published December 2021.

Nicolaides, A. (2010). 'The Laos tou Theou - an orthodox view of the "people of God"', HTS Teologiese Studies/Theological Studies, 66(1).

Oduyoye (1984). Violence against Women: A Challenge to Christian Theology JITI, 1. In E. Fiorenza (Ed.), Memory of Her: A Feminist Theological Reconstruction of Christian Theology.

Payne, B. P. (2009). Payne, Man and Woman, One in Christ, Grand Rapids: Zondervan.

Ragonese, C., Shand, T. \& Barker, G. (2019). Masculine norms and men's health: Making the connections. Washington, DC: Promundo-US.

Republic of South Africa (2013). Department of Women, Children and People with Disabilities. Background Paper: Women's Empowerment and Gender Equality 1994-2024.

Republic of South Africa (2014). Twenty-year review: South Africa, 1994-2014. Viewed the 11 August 2021. [Available online at

https://www.dpme.gove.za/news/Documents/20percent20Yearpercent20]

Republic of South Africa (2020). Crimes against women in South Africa, an analysis of the phenomenon of GBV and femicide: An overview of the prevalence of crimes against women in the country and the conditions that exacerbate GBV leading to femicide. Viewed on the 05 August 2021. Website: Microsoft PowerPoint - GBV and Femicide Final Stats SA (parliament.gov.za) 
Republic of South Africa (2015). The status of women in the South African economy. Department of Women. Viewed the $11^{\text {th }}$ of August 2021. [Available online at https://www.gov.za/ sites/default/files/gcis_document/201508/statusofwomeninsaeconomy.pdf]

Republic of South Africa (2020). South African response to the request by the Special Rapporteur on violence against women, its causes and consequences on the collection of information on prevention activities, including through the collection of data on femicide or gender-related killings of women. Department of Women, Youth and Persons with Disabilities. Viewed the 11th of August 2021. [Available online at https://www.ohchr.org/ Documents/Issues/Women/SR/Femicide/2020/States/submission-south-africa.pdf]

Ridge, D., Emslie, C. \& White, A. (2011). Understanding how men experience, express and cope with mental distress: Where next? Sociology of Health \& IIIness, 33(1), 145-159.

Ruddick, S. (1998). Cited in C. Cockburn. (1999) "Gender, Armed Conflict and Political Violence." Background Paper for Gender, Armed Conflict and Political Violence. World Bank Conference.

Social Science and Reproductive Health Research Network. (2001). Gender socialization and male responsibility in the family: A comparative analysis of three sociocultural groups in Nigeria. Annals of the Social Science Academy of Nigeria, 13, 92-108.

Staiger, T., Stiawa, M., Mueller-Stierlin, A.S., Kilian, R., Beschoner, P., Gündel, H., Becker, T., Frasch, K., Panzirsch, M., Schmauß, M. \& Krumm, S. (2020). Masculinity and help-seeking among men with depression: A qualitative study. Frontiers in Psychiatry, the 24 November 2020. [Available online at https://doi.org10.3389/fpsyt.2020.599039]

Stats South Africa. (2018). Crimes against women in South Africa, an analysis of the phenomenon on GBV and femicide. An overview of the prevalence of crimes against women in the country and the conditions that exacerbate GBV leading to femicide. Department of Statistics South Africa. Viewed the $11^{\text {th }}$ of August 2021. [Available online at https://www.paliament.gov.za/storage/app/media/1Stock/Events_Intstitutional/2020/ womens_charter_2020/docs/30-07-2020/A_Stastistical_Overview]

Stats South Africa. (2018). Marriages and divorces. Department of Statistics South Africa. Viewed on the $11^{\text {th }}$ October 2021. [Available online at https://www.statssa.gov.za/publications/P0307/P03072018.pdf]

Taylor, B. (2020). George Floyd: Timeline of Black deaths and protests. BBC News 22 April.

Thobejane, T.D. \& Luthonda, V. (2019). An investigation into the trend of domestic violence on men: The case of South Africa. OIDA International Journal of Sustainable Development. Ontario International Development Agency: Canada.

Turshen, M., Lindsay, L.A. \& Miescher, S.F. (editors). (2004). Men and masculinities in modern Africa. (Social history of Africa). Portsmouth: Heinemann.

United Nations, Department of Economic and Social Affairs, Population Division. (2021). World Population, Prospects 2021: Highlights (ST/ESA/SER.A/423). 
cc) (i) $\ominus$ Pharos Journal of Theology ISSN 2414-3324 online Volume 102 - (2021)

cC. EY NO NO Copyright: @2021 Open Access/Author/s - Online @ http//: www.pharosjot.com

Van Klinken, A.S. (2011). Male headship as male agency: An alternative understanding of a "patriarchal" African Pentecostal discourse on masculinity and gender. Religion and Gender, 1(1), 104-124. 